\title{
Strategi Belajar Dengan Memanfaatkan e-Learning Pada Masa Pandemi Di SDN 2 Kembang Kerang Aikmel
}

\author{
${ }^{1}$ Elfa Yuliana \& ${ }^{2}$ Saepul Bahri \\ Institut Agama Islam Hamzanwadi NW Pancor \\ elfayuliana0480@gmail.com
}

\begin{abstract}
Abstrak
Penelitian ini bertujuan untuk mendeskripsikan bagaimana strategi belajar dengan memanfaatkan e-learning pada masa pandemi, dan apa saja faktor-faktor pendukung dan penghambat dalam penerapan strategi belajar dengan pemanfaatan e-learning pada masa pandemi.

Penelitian ini menggunakan pendekatan kualitatif deskriptif dengan subjek penelitian guru dan siswa. Adapun teknik pengumpulan data yang digunakan yaitu observasi, wawancara, dan dokumentasi. Keabsahan data diuji dengan menggunakan triangulasi sumber, yaitu memeriksa kembali data yang diperoleh melalui beberapa sumber.

Hasil penelitian menunjukkan bahwa: (1) strategi belajar dengan memanfaatkan e-learning pada masa pandemi di Sekolah Dasar Negeri 2 Kembang Kerang didasari atas ketidak bolehan dalam melakukan pembelajaran secara langsung pada masa pandemi covid 19 atau virus corona (2) Faktor-faktor pendukung dan penghambat dalam penerapan strategi belajar dengan pemanfaatan e-learning pada masa pandemi, adapun faktor pendorong strategi belajar dengan memanfaatkan e-learning pada masa pandemi yaitu: motivasi dalam penggunaan dan pengaplikasian internet sangat besar dalam melakukan pembelajaran, baik dari kepala sekolah, guru, maupun siswa, sarana prasarana yang dimiliki sudah lumayan untuk penerapan e-learning. Faktor penghambat: terbatasnya kemampuan guru dalam mengaplikasikan pembelajaran e-learning di sekolah, sumber daya manusia yang belum optimal dalam penerapan strategi belajar dengan memanfaatkan e-learning, belum adanya website e-learning, dan kesadaran semua pihak dalam pentingnya pembelajaran e-learning dalam memajukan pendidikan di sekolah masih sedikit.
\end{abstract}

Kata kunci: strategi, belajar, e-learning. 


\section{PENDAHULUAN}

Strategi pembelajaran adalah suatu kegiatan pembelajaran yang harus dikerjakan guru dan siswa agar tujuan pembelajaran dapat dicapai secara efektif dan efesien. ${ }^{1}$ Pada era global ini, internet merupakan media yang sangat cepat dalam perkembangannya. Semua informasi tersedia di internet dan dapat diakses oleh siapa saja dengan mudah, fleksibel, cepat, dan akurat. Hal inilah yang melandasi ide untuk memanfaatkan internet sebagai media pembelajaran dalam rangka memajukan pendidikan di Indonesia.

E-learning adalah belajar dengan menggunakan bantuan alat elektronik lebih jelasnya, e-learning adalah suatu proses belajar mengajar antara guru dan siswa, tanpa harus bertatap muka satu dengan yang lain. Dengan bantuan alat elektronik (tepatnya PC) yang terkoneksi dengan internet, siswa dapat belajar di manapun dan kapanpun tanpa harus datang ke kampus atau ke sekolah. ${ }^{2}$

Pada masa pandemi covid 19 ini, penggunaan atau pemanfaatan e-learning atau alat elektronik yang berupa laptop atau handphone yang tersambung akses internet ini sangatlah cocok digunakan karena keterbatasan ruang dalam bertatap muka.

Menurut Yaniawati (2010) e-learning dapat memperluas peran, cakrawala dan jangkauan dalam proses pembelajaran peserta didik namun berdasarkan penelitian yang dilakukan oleh peneliti di LPTK hanya 30\% siswa yang mengetahui e-learning. ${ }^{3}$

Sesuai dengan pernyataan di atas bahwa ketidak tahuan siswa tersebut dikarenakan tidak adanya pengenalan yang dilakukan oleh tim penyusun $e$ learning ke sekolah-sekolah dan kurangnya guru yang memperkenalkan kepada siswa sebab tidak memungkinkan untuk digunakan, namun pada saat ini atau pada masa pandemi ini kita dihadapkan pada persoalan yang malah mengharuskan kita untuk menggunakan media tersebut dalam rangka mencapai tujuan belajar.

\footnotetext{
${ }^{1}$ Olivia Cherly Wuwung, Strategi Pembelajaran Dan Kecerdasan Emosional (Surabaya: Scopindo, Cet.I, 2020), hlm. 32.

${ }^{2}$ Hamdani, Strategi Belajar Mengajar (Bandung: Pustaka Setia, Cet. X, 2011), hlm. 112

${ }^{3}$ Lidia Simanihuruk, et.al., Implementasi, Strategi Dan Inovasinya (Medan: Yayasan Kita Menulis, cet. I, 2019), hlm. 3
} 
Meskipun pada dasarnya banyak sekali metode, media, strategi pembelajaran yang ditawarkan oleh para peneliti pembelajaran atau para ilmuwan dalam rangka agar proses pembelajaran berlangsung dengan baik dan tepat waktu dan hasil pembelajarannyapun mencapai kompetensi yang telah ditentukan baik pihak satuan pendidikan ataupun pihak yang menyelenggarakan pendidikan tersebut atau pemerintah.

Dari sekian banyak strategi pembelajaran yang diterapkan oleh guru di dalam kelas, namun yang paling cocok pada masa pandemi covid 19 ini adalah strategi dengan memanfaatkan e-learning. Yaitu Strategi dengan pemanfaatan alat elektronik yang terakses internet ini dimaksudkan sebagai cara untuk menjelaskan sesuatu (bahan pelajaran) melalui alat-alat elektonik atau yang sering disebut dengan e-learning, strategi ini bertujuan untuk membantu guru dan peserta didik dalam melakukan proses pembelajaran, sehingga pembelajaran dapat dilakukan meskipun di masa covid 19, keterbatasan ruang dalam bertatap muka, dan juga dapat membentuk siswa dalam memanfaatkan alat elektroniknya entah itu berupa laptop atau handphone sebagai alat untuk melakukan proses pembelajaran.

Oleh karena itu, hal ini harus menjadi perhatian dan pemikiran lebih-lebih guru untuk dapat mengatasi masalah dalam melakukan pembelajaran jarak jauh saat ini. Mencari faktor penyebab, mencari solusi pemecahan masalah saat ini yang dialami pada masa covid 19 atau pandemi. Serta mengupayakan perbaikan dengan penerapan inovasi pembelajaran untuk mengembangkan proses pembelajaran yang lebih baik lagi sehingga dapat mencapai tujuan pembelajaran yang telah ditetapkan secara maksimal. Upaya yang dilakukan guru adalah dengan memanfaatkan e-learning pada masa pandemi. 


\section{METODE PENELITIAN}

\section{Tempat dan Waktu Penelitian}

1. Tempat penelitian

Sekolah Dasar Negeri 2 Kembang Kerang dan siswa yang melakukan pembelajaran di lingkungan masyarakat yang terkait dengan strategi belajar dalam memanfaatkan e-learning pada masa pandemi ini.

2. Waktu penelitian

Penelitian dilakukan pada saat masa pandemi covid 19 bulan Maret sampai bulan September 2020.

\section{Metode Penelitian}

Metode penelitian yang digunakan adalah metode penelitian kualitatif deskriptif. Metode penelitian kualitatif sering disebut metode penelitian naturalistic karena penelitiannya dilakukan pada kondisi yang alamiah (natural setting); di sebut juga sebagai metode etnogtaphi, karena pada awalnya metode ini lebih banyak digunakan untuk penelitian bidang antropologi budaya; disebut sebagai metode kualitatif, karena data yang dikumpulkan dan analisisnya lebih bersifat kualitatif ${ }^{4}$

Menurut Denzin dan Lincoln (1994) menyatakan bahwa penelitian kualitatif adalah penelitian yang menggunakan latar alamiah dengan maksud menafsirkan fenomena yang terjadi dan dilakukan dengan jalan melibatkan sebagian metode yang ada. Erickson (1968) menyatakan bahwa penelitian kualitatif berusaha untuk menemukan dan menggambarkan secara naratif kegiatan yang dilakukan dan dampak dari tindakan yang dilakukan terhadap kehidupan mereka.

\footnotetext{
${ }^{4}$ Sugiyono, Metode Penelitian Pendidikan Pendekatan Kuantitatif, Kualitatif, dan R\&D (Bandung; ALFABETA, CV, Cet,XXIII), hlm. 14.
} 


\section{Prosedur Pengumpulan dan Pengolahan Data}

Untuk memberikan gambaran mengenai prosedur dalam penelitian ini, berikut akan diuraikan setiap tahapannya:

1. Observasi awal

Peneliti hanya mengobservasi kegiatan belajar yang dilakukan oleh guru di sekolah dan siswa di rumah pada masa pandemi covid 19 dan dengan mengkaitkan masalah yang peneliti bawa sebelumnya dan kemudian peneliti melakukan penjajahan umum dan menyeluruh serta melakukan deskripsi terhadap semua hal yang dilihat dan dialami.

2. Tahap Eksplorasi

Pada tahap ini peneliti melakukan pengumpulan data, untuk dianalisis dalam rangka memecahkan masalah . Di samping itu, pada tahap inipun peneliti juga telah melakukan penafsiran data untuk mengetahui maknanya dalam konteks keseluruhan masalah sesuai dengan situasi alami, terutama menurut sudut pandang sumber datanya.

3. Tahap pengecekan kebenaran hasil

Hasil penelitian yang sudah tersusun ataupun yang belum tersusun sebagai laporan dan bahkan penafsiran data, perlu dicek kebenarannya sehingga ketika di distribusikan tidak terdapat keragu-raguan. Pengecekan tersebut peneliti lakukan dengan menggunakan teknik triangulasi sumber dan metode.

Keberhasilan peneliti sebagai sumber tergantung pada teknikteknik pengumpulan data yang digunakan. Pengumpulan data dalam penelitian ini dimaksudkan untuk memperoleh bahan-bahan, keterangan, kenyataan-kenyataan dan informasi yang dapat dipercaya. Untuk memperoleh data seperti prosedur-prosedur, alat-alat serta kegiatan nyata, penulis menentukan teknik pengumpulan data yang digunakan sebagai berikut:
a. Obsevasi
b. Wawancara
c. Dokumentasi 


\section{A. Pemeriksaan atau Pengecekan Keabsahan Data}

Untuk memeriksa objektivitas dan keabsahan data pada penelitian ini, peneliti menggunakan teknik triangulasi. Menurut Sugiyono (2010: 330) teknik triangulasi diartikan sebagai teknik pengumpulan data yang bersifat menggabungkan dari berbagai teknik pengumpulan data dan sumber data yang telah ada.

\section{B. Analisis data}

1. Pengumpulan Data

Kegiatan ini digunakan untuk memperoleh informasi yang berupa kalimatkalimat yang dikumpulkan melalui kegiatan observasi, dan dokumen. Data yang diperoleh masih berupa data yang mentah yang tidak teratur, sehingga diperlukan analisis agar data menjadi teratur.

2. Reduksi Data

Merupakan suatu proses seleksi, pengfokusan penyederhanaan dan abstraksi dari field note (data mentah).

3. Sajian Data

Merupakan rakitan dari organisasi informasi yang memungkinkan kesimpulan riset dapat dilakukan. Sajian data dapat berupa matriks, gambar atau skema, jaringan kerja kegiatan dan tabel. Semuanya dirakit secara teratur guna mempermudah pemahaman informasi.

4. Penarikan Kesimpulan

Kesimpulan akhir akan diperoleh bukan hanya sampai pada akhir pengumpulan data, melainkan dibutuhkan suatu verifikasi yang berupa pengulangan dengan melihat kembali field note (data mentah) agar kesimpulan yang diambil lebih kuat dan bisa dipertanggungjawabkan. 


\section{HASIL PENELITIAN DAN PEMBAHASAN}

\section{Pembahasan}

1. Program pemanfaatan E-Learning pada masa pandemi di sekolah.

Strategi belajar dengan memanfaatkan e-learning pada masa pandemi di sekolah-sekolah sekitaran tempat peneliti ditinjau dari segi Sumber Daya Manusia (SDM)

Strategi belajar dengan memanfaatkan e-learning pada masa pandemi covid 19 ini merupakan suatu usaha yang dilakukan sekolah dalam memeberikan pembelajaran pada masa pandemi covid 19 yang lebih baik dan mudah dipahami. Faktor yang berpengaruh dalam strategi belajar dengan memanfaatkan e-learning tersebut dilihat dari Sumber Daya Manusia yang ditinjau dalam pelaksanaan e-learning adalah guru dan siswa sekolah tempat peneliti melakukan penelitian yang merupakan pengguna e-learning pada setiap pembelajaran.

Guru mempunyai peranan penting dalam penerapan e-learning karena guru sebagai pihak yang memberikan arahan dalam proses pembelajaran. Guru sangat mendukung penggunaan e-learning pada saat proses pembelajaran, karena dinilai dapat memudahkan proses belajar mengajar. Tetapi pelaksanaan e-learning terkendala oleh faktor usia. Usia guru yang sudah lanjut dinilai menjadi salah satu faktor penghambat terselenggaranya pembelajaran berbasis e-learning. Sekitar 80-90\% guru dari total guru yang ada di sekolah-sekolah sekitaran tempat penelitian sudah dapat mengoperasikan komputer, namun tidak sedikit guru yang tidak bisa mengoperasikan komputer dikarenakan faktor usia, dan mereka enggan untuk belajar.

2. Kendala yang dihadapi dalam Strategi belajar dengan memanfaatkan $E$ Learning di SDN 2 Kembang Kerang

Kendala adalah permasalahan yang muncul dalam suatu strategi belajar dengan memanfaatkan, yang perlu dicarikan solusi untuk memecahkan masalah tersebut, dalam hal ini kendala terjadi karena tidak sesuainya harapan dengan kenyataan pada penerapannya. Oleh karena itu kendala tersebut diperjelas dan dicari sumber masalahnya, sehingga akan menemukan pemecah 
dari masalah tersebut. Kaitan dalam strategi belajar dengan memanfaatkan $e$ learning di masa pandemi di SD Negeri 2 Kembang Kerang pastinya ditemui beberapa kendala yang berarti, di antaranya yaitu:

a. Kendala dari Segi Sumber Daya Manusia

Kendala yang dihadapi dari segi sumber daya manusia (SDM) dalam strategi belajar dengan memanfaatkan e-learning di sekolah-sekolah sekitaran tempat peneliti yaitu masih minimnya pemahaman guru dalam pembelajaran berbasis e-learning serta komitmen dalam menggunakan pembelajaran e-learning tersebut yang masih minim menjadikan pelaksanaan pembelajaran e-learning belum berhasil. Kompetensi guru yang masih kurang dan motivasi guru dalam mengaplikasikannya juga masih rendah menjadikan kesiapan pembelajaran 4 tahun yang lalu belum terlaksana dengan baik.

Sedangkan kendala dari siswa dalam strategi belajar dengan memanfaatkan e-learning di SD Negeri 2 Kembang Kerang yaitu SDM yang masih kurang baik kesadaran untuk belajar mandiri maupun dalam memanfaatkan pembelajaran e-learning serta masih terpakunya siswa kepada guru yang aktif di kelas membuat pembelajaran tersebut masih kurang dapat diterima. Sumber daya manusia di sini juga masih terkendala karena faktor ekonomi siswa yang belum mampu menggunakan pembelajaran berbasis e-learning karena merupakan siswa dengan tingkat ekonomi menengah ke bawah.

b. Kendala dari Segi Materi Atau Bahan Ajar

Penggunaan internet yang belum sepenuhnya menyeluruh digunakan oleh semua guru dan murid terutama untuk guru yang masih minim pengetahuan tentang internet membuat pembelajaran menggunakan $e$ learning belum dapat berjalan dengan baik. Minimnya sumber materi belajar dan bahan ajar yang digunakan menjadikan pembelajaran tersebut masih terkendala, pemanfaatan sumber belajar dan bahan ajar belum sepenuhnya dimanfaatkan dengan baik. 
Minimnya ketersediaan bahan ajar yang diupload atau didownload oleh siswa maupun guru masih belum beragam, file-file yang dipergunakan juga masih sedikit.

\section{KESIMPULAN}

Berdasarkan rumusan masalah serta hasil penelitian dan pembahasan yang telah dijelaskan di atas dapat disimpulkan bahwa:

1. Strategi belajar dengan memanfaatkan e-learning pada masa pandemi, dalam penggunaan e-learning di SD Negeri 2 Kembang Kerang masih sebatas menggunakan blog, kadang di youtube mencari pembelajaran maupun mencari berita. Mengolahnya juga sebatas memindahkan dari materi yang didapat kemudian dipaparkan dan dijelaskan ke siswa.

2. Faktor-faktor pendukung dan penghambat dalam penerapan penerapan $e$ learning yang didukung dengan adanya SDM yang baik tentunya akan memberikan dampak positif dalam strategi belajar dengan memanfaatkan pembelajaran tersebut, adapun faktor penghambat atau kendala yaitu kendala dari segi SDM yaitu kemampuan dan kemauan guru dalam menggunakan $e$ learning masih kurang. 


\section{DAFTAR PUSTAKA}

Hamdani, Strategi Belajar Mengajar, Bandung: Pustaka Setia, Cet. X, 2011.

Prastiyo, Fendika, Peningkatan Hasil Belajar Peserta Didik Dengan Model Kooperatif Jigsaw Pada Materi Pecahan Di Kelas V SDN Sepanjang 2, Surakarta: Kekata Publisher, Cet, I, 2019.

Simanihuruk, Lidia, et.al., E-Learning; Implementasi, Strategi Dan Inovasinya, Medan: Yayasan Kita Menulis, Cet. I, 2019

Simatupang, Halim, Strategi Belajar Mengajar Abad Ke-21, Surabaya: Pustaka Media Guru, Cet, I, 2019.

Sugiyono, Metode Penelitian Pendidikan Pendekatan Kuantitatif, Kualitatif R\&D, Bandung: Alfabeta, Cet, XXIII, 2016.

Wuwung, Olivia Cherly, Strategi Pembelajaran Dan Kecerdasan Emosional, Surabaya; Scopindo, Cet.I, 2020. 